Published every January - June and July - December
JURNAL ASET (AKUNTANSI RISET)
ISSN : 2541-0342 (Online). ISSN : 2086-2563 (Print). http://ejournal.upi.edu/index.php/aset

\title{
Pengaruh Skeptisisme Professional dan Kompetensi Auditor Terhadap Jumlah Temuan Audit
}

\author{
Hetti Herawati ${ }^{1}$, Yeni Rewinda Lubis ${ }^{2}$ \\ Jurusan Akuntansi, Fakultas Ekonomi, Universitas Sangga Buana YPKP, Bandung, Indonesia.
}

\begin{abstract}
The purpose of this research is to know the influence of Professional Skepticism and competence of Auditors Against the number of Audit Findings the audit process in carrying out both partially or simultaneous. The object of the research is a public accountant in North Bandung area. The method in this research is descriptive causal, and acquisition of data is done with the dissemination of the questionnaire. In analyzing the data used multiple regression. The hypothesis in this study: "Professional Skepticism and the competence of the Auditor's positive effect against the number of Audit Findings". The results showed that, either partially or simultaneously, professional skepticism and the competence of the auditor effect significantly to the amount of the audit findings, it is supported by the results of a test that showed the value of the Fhitung and tcount is greater than the value of $F$ t table and the table.
\end{abstract}

Keywords. profesional skepticism; competence auditor; audit findings.

Abstrak. Tujuan dari penelitian ini adalah untuk mengetahui Pengaruh Skeptisisme Professional dan Kompetensi Auditor Terhadap Jumlah Temuan Audit dalam melaksanakan proses audit baik secara parsial maupun simultan. Objek dari penelitian adalah Kantor Akuntan Publik di wilayah Bandung Utara. Metode dalam penelitian ini adalah deskriptif kausal, dan perolehan data dilakukan dengan penyebaran kuesioner. Dalam menganalisis data digunakan regresi berganda. Hipotesis dalam penelitian ini : "Skeptisisme Professional dan Kompetensi Auditor berpengaruh positif terhadap Jumlah Temuan Audit”. Hasil penelitian menunjukkan bahwa, baik secara parsial maupun secara simultan, skeptisisme professional dan kompetensi auditor berpengaruh signifikan terhadap jumlah temuan audit, hal ini didukung dengan hasil pengujian yang menunjukkan Nilai $F_{\text {hitung }}$ dan $t$ hitung lebih besar dari nilai F tabel dan t tabel.

Kata Kunci. skeptisisme professional; kompetensi auditor; temuan audit.

Corresponding author. J1. PHH Mustofa (Suci) No 68. Kota Bandung. Provinsi Jawa Barat. Email: hetti.herawati67@gmail.com. Email yenni.lubis@ rocketmail.com

How to cite this article. Herawati, Lubis. (2015). Pengaruh Skeptisme Profesional dan Kompetensi Auditor Terhadap Jumlah Temuan Audit. Jurnal Aset (Akuntansi Riset). Program Studi Akuntansi Fakultas Pendidikan Indonesia Universitas Pendidikan Indonesia, 7 (2), 1-15. Retrieved from http://ejournal.upi.edu/index.php/aset History of article. Received: Juli 2015, Revision: September 2015, Published: Desember 2015 


\section{PENDAHULUAN}

Auditor adalah pihak ahli yang dipercaya mampu memberikan akurasi informasi bagi pemakai ditengah munculnya berbagai kecurangan atau fraud yang semakin berkualitas. Wilopo (2006) mengatakan bahwa kecurangan akuntansi telah berkembang di berbagai negara termasuk di Indonesia. Selain kecurangan akuntansi, perilaku tidak etis juga mempengaruhi banyaknya penyimpangan penyimpangan yang terjadi di Indonesia. (Fauwzi, 2011) Perilaku tidak etis yaitu perilaku menyimpang yang dilakukan seseorang untuk mencapai suatu tujuan tertentu. Hal ini mendorong auditior terus berupaya meningkatkan kualitas bukan hanya dibidang pengetahuan tapi juga dalam hal objektivitas dalam pemeriksaan sehingga benar benar mampu menggunakan kemahiran jabatannya. Selain pendidikan formal, pendidikan informal berkelanjutan harus terus diupayakan agar auditor memiliki up date informasi dibidangnya.

Menyikapi pentingnya opini audit terhadap pengguna, maka auditor dituntut untuk mampu meminimalisir kesalahan dalam pemeriksaannya. Auditor harus menggunakan kemahiran profesional secara cermat dan seksama dalam menentukan jenis pemeriksaan yang akan dilaksanakan, dan standar yang akan diterapkan terhadap pemeriksaan yang dilakukan.

Berdasarkan Prinsip Dasar Kode Etik Profesi Akuntan Publik (IAPI, 2010) seksi:100.4 Setiap praktisi wajib mematuhi Prinsip Dasar Etika Profesi yaitu prinsip kompetensi serta sikap kecermatan dan kehatihatian profesional. Yaitu setiap praktisi wajib memlihara pengetahuan dan keahlian profesionalnya pada suatu tingkatan yang dipersyaratkan secara berkesinambungan, sehingga klien atau pemberi kerja dapat menerima jasa profesional yang diberikan secara kompeten berdasarkan perkembangan terkini dalam praktik, perundang-undangan, dan metode pelaksanaan pekerjaan. Setiap praktisi harus bertindak secara profesional dan sesuai dengan standar dan kode etik yang berlaku dalam memberikan jasa profesionalnya.

Tujuan auditor menurut ISA 200 ialah memperoleh asurans yang memadai bahwa laporan keuangan bebas dari salah saji material baik yang disebabkan oleh error maupun fraud. Seorang auditor dituntut memiliki kemampuan profesional yang tinggi yaitu dapat mengkombinasikan pengalaman dan kemampuan teknis/analisis yang cukup baik untuk memahami dan mencari solusi terhadap permasalahan yang timbul pada saat pelaksanaan audit. Kemampuan kerja auditor mempengaruhi kualitas hasil audit yang telah dilaksanakan dalam hal ini adalah kemampuan pendeteksian temuan. (Agusti Restu dan Pertiwi Nastia Putri, 2013)

Deteksi temuan adalah hasrat tujuan yang ditetapkan dalam langkah kerja audit dalam mengkombinasikan pemikiranpemikiran dengan data kondisi yang ada untuk mendapatkan segala bentuk bukti kebenaran terjadinya penyimpangan dalam pelaksanaannya. Kemampuan pendeteksian temuan sangat dipengaruhi oleh faktor kompetensi auditor dalam melaksanakan, sehingga auditor yang profesional akan menghasilkan nilai/mutu temuan atas pelaksanaan tugasnya. (Herawaty Arleen , Susanto Yulius Kurnia , 2010 ). Kompetensi yang dimaksud adalah pengalaman serta keahlian auditor dalam melakukan audit laporan keuangan baik dari segi lamanya waktu, maupun banyaknya penugasan yang pernah dilakukan dan tingkat pendidikan serta sertifikasi yang dimilikinya.

Pengalaman kerja auditor dipandang sebagai faktor penting dalam kegiatan pemeriksaan, tak dapat disangkal bahwa pengalaman merupakan guru terbaik dalam meningkatkan kualitas seseorang. Semakin banyak pengalaman seorang auditor, maka akan semakin banyak jenis permasalahan yang ditemui dan semakin variatif solusi yang ditawarkan untuk mengatasi permasalahan yang ada. Auditor yang berpengalaman mampu menunjukkan proyeksi error yang lebih baik dari pada level junior.

Pemeriksaan keuangan tidak bisa dilakukan oleh sembarang orang, tetapi harus dilakukan 
oleh orang yang memiliki kompetensi dibidangnya dengan didukung oleh sikap skeptime profesionalnya. Hal ini akan sangat berpengaruh terhadap proses pengumpulan bukti yang akan digunakan sebagai dasar dalam menentukan lingkup pemeriksaan, memilih metodologi, menentukan jenis dan jumlah bukti yang akan dikumpulkan, atau dalam memilih pengujian dan prosedur untuk melaksanakan pemeriksaan. Intinya Skeptisisme profesional sangat diperlukan untuk meningkatkan kualitas audit, karena dengan bersikap skeptis, auditor akan lebih berinisiatif untuk mencari informasi lebih lanjut dari manajemen mengenai keputusankeputusan akuntansi yang diambil, dan menilai kinerjanya sendiri.

\section{Rumusan Masalah}

Bagaimana pengaruh skeptisisme professional dan kompetensi auditor terhadap jumlah temuan audit secara parsial, dan Bagaimana pengaruh skeptisisme professional dan kompetensi auditor terhadap jumlah temuan audit

\section{Tujuan dan Manfaat Penelitian.}

Tujuan dari penelitian ini adalah : Untuk mengetahui bagaimana pengaruh skeptisisme professional dan kompetensi auditor secara parsial terhadap jumlah temuan audit dan Untuk mengetahui bagaimana pengaruh skeptisisme professional dan kompetensi auditor secara simultan berpengaruh terhadap jumlah temuan audit. Penelitian ini diharapkan akan memberikan manfaat pada kantor akuntan publik agar terus meningkatkan sikap skeptisme profesional dan kompetensinya dalam kegiatan pemeriksaan, serta menjadi pengetahuan bagi pemakai dalam menetukan kantor akuntan publik yang berkualitas.

\section{KAJIAN LITERATUR}

Auditor mempunyai tugas dan tanggung jawab yang sangat besar, karenanya: "Auditor wajib merancang dan melaksanakan prosedur audit selanjutnya yang sifatnya, waktunya dan luasnya didasarkan atas dan bersifat responsif terhadap risiko salah saji material yang dinilai pada tingkat asersi". Tuanakotta (2015:193). Auditor harus memiliki kualifikasi untuk memahami kriteria yang digunakan dan harus kompeten untuk mengetahui jenis serta jumlah bukti audit yang akan dikumpulkan untuk dapat menarik kesimpulan yang tepat setelah pengevaluasian bukti, setelah itu dalam tahap terakhir proses auditing adalah menyiapkan laporan audit (audit report), sekaligus menyampaikan temuan-temuan auditor kepada pemakai selama pelaksanaan audit.

Manajemen perusahaan mempunyai tanggung jawab atas penyajian laporan keuangan. Laporan keuangan harus disusun sebaik mungkin sesuai dengan data yang akurat sesuai aturan akuntansi yang berlaku. ( PSAK No.01; Paragraf ke 24) Mengingat laporan keuangan merupakan informasi yang sangat berguna bagi pemakai, maka laporan keuangan harus dapat dipahami, relevan, andal, dan dapat diperbandingkan.

Namun pada kenyataannya masih terjadi tindakan penyimpangan pada laporan keuangan suatu perusahaan, sehingga informasi yang ada dalam laporan keuangan menjadi tidak relevan dan tidak dapat diandalkan. Tindakan penyimpangan dalam laporan keuangan ini merupakan salah satu tindakan kecurangan akuntansi. Tindakan yang dilakukan dapat berupa penghilangan jumlah atau pengungkapan dalam laporan keuangan untuk mengelabui pemakai laporan keuangan. Wilopo (2006) dalam Nur Ratri Kusumastuti, mengatakan bahwa kecurangan akuntansi telah berkembang di berbagai negara termasuk di Indonesia. Selain kecurangan akuntansi, perilaku tidak etis juga mempengaruhi banyaknya penyimpangan penyimpangan yang terjadi di Indonesia (Fauwzi, 2011). Perilaku tidak etis yaitu perilaku menyimpang yang dilakukan seseorang untuk mencapai suatu tujuan tertentu. Menurut Fauwzi (2011) dalam Nur Ratri Kusumastuti , tindakan tidak etis dan tindakan curang dapat dipengaruhi oleh adanya sistem pengendalian internal dan monitoring oleh atasan. Untuk mendapatkan hasil monitoring yang baik, diperlukan pengendalian internal perusahaan yang efektif (Wilopo, 2006). 
Teori keagenan (Jensen and Meckling, 1976) dalam Nur Ratri Kusumastuti sering digunakan untuk menjelaskan kecurangan akuntansi. Teori keagenan bermaksud memecahkan dua problem yang terjadi dalam hubungan keagenan. Permasalahan yang timbul akibat adanya perbedaan kepentingan antara prinsipal dan agen disebut dengan agency problems . Salah satu penyebab agency problems adalah adanya asimetri informasi

Penggunaan jasa eksternal audit merupakan salah satu aktivitas pengendalian yang baik untuk dilakukan perusahaan. Hal ini dilakukan untuk menaikkan citra dan kepercayaan perusahaan dari stakeholder, serta untuk menjaga asset perusahaan dari tindakan kecurangan oleh pegawai dilingkungan perusahaan (Hilmi, Fakhri. 2011).. Untuk itu maka auditor harus merencanakan dan melaksanakan audit dengan skeptisisme professional mengingat adanya kondisi yang mungkin menyebabkan terjadinya salah saji material atas laporan keuangan.( S Noviyanti ;2008). Skeptisisme profesional adalah sikap yang mencakup pikiran yang mempertanyakan dan sebuah penilaian kritis terhadap bukti-bukti audit. Auditor harus mempertahankan tingkat tertentu skeptisisme profesional dalam mendeteksi kecurangan pada laporan keuangan karena pelaku menyembunyikan penyimpangan yang dihasilkan SPA (IAPI 2013 seksi 200)

Disamping sikap skeptisme profesional, seorang auditor harus kompeten dalam bidangnya, karena kompetensi merupakan keterampilan yang diperlukan untuk melakukan audit internal yang efektif. Berikut beberapa kunci dari kompetensi : Keterampilan wawancara, Keterampilan analisis, Pengujian dan analisis keterampilan, keterampilan dokumentasi, Merekomendasikan hasil dan tindakan korektif, Keterampilan komunikasi. Negosiasi keterampilan, dan komitmen untuk belajar. (Moeller Robert, brink ; 2009 )

Spencer dan Spencer dalam MasImam.Com, Palan (2007:84) mengemukakan bahwa kompetensi menunjukkan karakteristik yang mendasari perilaku yang menggambarkan motif, karakteristik pribadi (ciri khas), konsep diri, nilai-nilai, pengetahuan atau keahlian yang dibawa seseorang yang berkinerja unggul (superior performer) di tempat kerja. Ada 5 (lima) karakteristik yang membentuk kompetensi yakni: "Pengetahuan; Faktor pengetahuan meliputi masalah teknis, administratif, proses kemanusiaan, dan sistem, 2. Keterampilan; merujuk pada kemampuan seseorang untuk melakukan suatu kegiatan, 3 . Konsep diri dan nilai-nilai; merujuk pada sikap, nilai-nilai dan citra diri seseorang, seperti kepercayaan seseorang bahwa dia bisa berhasil dalam suatu situasi, 4. Karakteristik pribadi; merujuk pada karakteristik fisik dan konsistensi tanggapan terhadap situasi atau informasi, seperti pengendalian diri dan kemampuan untuk tetap tenang dibawah tekanan, 5. Motif; merupakan emosi, hasrat, kebutuhan psikologis atau dorongan-dorongan lain yang memicu tindakan.

Dilihat dari sisi sikap skeptisme profesionisme dan kompetensi yang dimiliki seorang auditor, maka aspek-aspek tersebut memiliki peran yang besar terhadap banyaknya jumlah temuan yang diperoleh auditor dalam melaksanakan audit. Aspek individual memiliki peranan yang cukup penting dalam mempengaruhi banyaknya jumlah temuan audit, hal ini terjadi karena aspek-aspek individual mempunyai pengaruh yang sangat besar terhadap perilaku individu. Dengan demikian skeptisisme professional dan kompetensi auditor sebagai dimensi aspek individual akan berpengaruh terhadap banyaknya jumlah temuan yang diperoleh auditor.

\section{METODOLOGI PENELITIAN}

Metode yang digunakan dalam penelitian ini adalah deskriptif kausalitas, merupakan hubungan yang bersifat sebab dan akibat yang berguna untuk menganalisis bagaimana suatu variabel mempengaruhi variabel lain. Sugiyono (2013:209). Jenis data yang digunakan adalah data kuantitatif dengan sumber data primer, yaitu data yang diperoleh langsung dari sumbernya, melalui hasil penyebaran kuesioner. Teknik analisis data dilakukan dengan menggunakan analisis 
regresi berganda, dengan terlebih dahulu melakukan transformasi data dari ordinal menjadi interval serta dilakukannya uji asumsi klasik. Penelitian terdiri dari tiga variabel dimana : Skeptisme Profesional $\left(\mathrm{X}_{1}\right)$, Kompetensi $\left(\mathrm{X}_{2}\right)$ dan Jumlah Temuan Audit (Y). Indikator variabel $\mathrm{X}_{1}$ diantaranya:1.Selalu menganggap manajemen bisa membuat kecurangan, 2. Sikap berpikir yang senantiasa mempertanyakan , 3. Waspada. Indikator variabel $\mathrm{X}_{2}$ teridiri dari: 1. Lamanya bekerja 2.Banyaknyatugas pemeriksaan (jam terbang). 3. Tingkat sertifikasi pendidikan. 4.Jenjang pendidikan sarjana formal. Indikator variabel Y meliputi:
1. Temuan Sistem Pengendalian Internal 2. Temuan Kepatuhan

\section{HASIL DAN PEMBAHASAN}

Penelitian dilakukan pada 6(enam) kantor akuntan publik di wilayah Bandung Utara. Questioner disebarkan hanya pada level Supervisor dan Partner. Jumlah kuesioner yang disebarkan sebanyak 50. Untuk menguji hipotesis yang menyatakan bahwa skeptisme profesional dan kompetensi auditor secara parsial berpengaruh signifikan terhadap temuan audit, digunakan rumus regresi sederhana, dan diperoleh hasil sebagai berikut

\section{Tabel 1.1 Hasil Analisis Regresi Sederhana}

\begin{tabular}{|c|c|c|c|c|c|c|}
\hline \multicolumn{7}{|c|}{ Coefficients $^{\mathrm{a}}$} \\
\hline & \multirow[b]{2}{*}{ Model } & \multicolumn{2}{|c|}{ Unstandardized Coefficients } & $\begin{array}{l}\text { Standardized } \\
\text { Coefficients }\end{array}$ & \multirow[b]{2}{*}{$\mathrm{t}$} & \multirow[b]{2}{*}{ Sig. } \\
\hline & & $\mathrm{B}$ & Std. Error & Beta & & \\
\hline \multirow[t]{2}{*}{1} & (Constant) & 8,108 & 4,528 & & $-1,791$ & 083 \\
\hline & Skeptisisme & ,981 & 042 & ,978 & 23,426 &, 000 \\
\hline
\end{tabular}

a. Dependent Variabel: Jumlah Temuan

Dari tabel diatas, diperoleh persamaan regresi

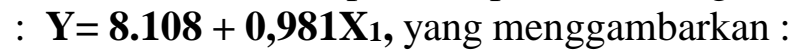
jika skeptisme profesional meningkat satu satuan, maka temuan audit akan meningkat senilai 0.981 dan koefisien regresi X1 bertanda positif yaitu sebesar 0,981 . Ini berarti bahwa ada pengaruh positif atas jumlah temuan audit. Pengaruh positif ini menunjukan, semakin tinggi penerapan skeptisime professional maka hasil jumlah temuan audit akan semakin tinggi. Disamping itu, dapat diketahui, pada tingkat signifikansi $5 \%$ dengan derajat kebebasan $\mathrm{dk}=33-2=31$, diperoleh $t_{\text {hitung }}$ sebesar 23, 426 dan $t_{\text {tabel }}$ 1,695.
Hal ini menunjukkan bahwa ,skeptisisme profesional sebagai sikap auditor yang senantiasa berpikir kritis dengan membuat berbagai dugaan dan menyusun berbagai pertanyaan, mampu meningkankan kuantitas maupun kualitas temuan audit. Hal inipun dibuktikan dengan nilai koefisien korelasi sebesar 0,969, yang menunjukkan hubungan yang sangat erat antara skeptisime professional dan temuan audit. Untuk itu Hipotesis " diterima".

Hasil uji analisis pada Pengaruh Kompetensi Auditor terhadap jumlah temuan audit dengan regresi sederhana, menunjukkan : 


\section{Tabel 1.2. Hasil Analisis Regresi Sederhana}

\begin{tabular}{|c|c|c|c|c|c|c|}
\hline \multicolumn{7}{|c|}{ Coefficients $^{\mathrm{a}}$} \\
\hline & \multirow[b]{2}{*}{ Model } & \multicolumn{2}{|c|}{ Unstandardized Coefficients } & $\begin{array}{c}\text { Standardized } \\
\text { Coefficients }\end{array}$ & \multirow[b]{2}{*}{$\mathrm{t}$} & \multirow[b]{2}{*}{ Sig. } \\
\hline & & $\mathrm{B}$ & Std. Error & Beta & & \\
\hline \multirow[t]{2}{*}{1} & (Constant) & 8,108 & 4,528 & & $-1,791$ &, 083 \\
\hline & Kompetensi &, 180 & 077 & ,098 & 2,345 &, 026 \\
\hline
\end{tabular}

a. Dependent Variabel: Jumlah Temuan

Dari tabel diatas, diperoleh persamaan regresi

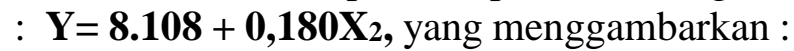
jika Kompetensi Auditor meningkat satu satuan, maka temuan audit akan meningkat senilai 8,108 dan koefisien regresi $\mathrm{X}_{2}$ bertanda positif yaitu sebesar 8,108 . Ini berarti bahwa ada pengaruh positif atas jumlah temuan audit. Pengaruh positif ini menunjukan, semakin Kompeten seorang auditor, maka hasil jumlah temuan audit akan semakin tinggi. Disamping itu, dapat diketahui, pada tingkat signifikansi $5 \%$ dengan derajat kebebasan $\mathrm{dk}=33-2=31$, diperoleh $t_{\text {hitung }}$ sebesar 2,345 dan $t_{\text {tabel }}$ 1,695. Hal ini menunjukkan bahwa ,kompetensi seorang auditor yang ahli dibidangnya serta didukung dengan keterampilan dalam berkomunikasi dan berstrategi, pengalaman dan attitude yang baik, maka akan mampu meningkankan kuantitas maupun kualitas temuan audit. Hal inipun dibuktikan dengan nilai koefisien korelasi sebesar 0,792, yang menunjukkan hubungan yang erat antara Kompetensi Auditor dan temuan audit. Untuk itu Hipotesis " diterima”.

Untuk mengetahui pengaruh skeptisme profesional dan kompetensi auditor terhadap jumlah temuan audit, dapat dilihat pada tabel berikut:

\section{Tabel 1.3 Hasil Analisis Regresi Berganda}

\begin{tabular}{|c|c|c|c|c|c|c|}
\hline \multicolumn{7}{|c|}{ Coefficients $^{\mathrm{a}}$} \\
\hline & \multirow[b]{2}{*}{ Model } & \multicolumn{2}{|c|}{ Unstandardized Coefficients } & $\begin{array}{l}\text { Standardized } \\
\text { Coefficients }\end{array}$ & \multirow[b]{2}{*}{$\mathrm{t}$} & \multirow[b]{2}{*}{ Sig. } \\
\hline & & $\mathrm{B}$ & Std. Error & Beta & & \\
\hline \multirow[t]{3}{*}{1} & (Constant) & 8,108 & 4,528 & & $-1,791$ & 083 \\
\hline & Skeptisisme & ,981 & 042 & ,978 & 23,426 & 000 \\
\hline & Kompetensi &, 180 & 077 & -098 & 2,345 & ,026 \\
\hline
\end{tabular}

a. Dependent Variabel: Jumlah Temuan

Dari tabel diatas, dapat diketahui bahwa Koefisien regresi $X_{1}$ dan $X_{2}$ bertanda positif yaitu sebesar 0,981 dan 0,180 . Ini berarti bahwa ada pengaruh positif atas jumlah temuan audit. Disamping itu dilakukan pengujian melalui uji $\mathrm{F}$, dengan tujuan untuk mengetahui apakah hipotesis ditolak atau diterima.

\section{Tabel 1.4 Hasil Uji F (Uji Regresi Simultan)}

\begin{tabular}{|c|c|c|c|c|c|c|}
\hline \multicolumn{7}{|c|}{ ANOVA $^{a}$} \\
\hline 1 & Regression & 28,675 & 2 & 14,337 & 274,396 &, $000^{\mathrm{b}}$ \\
\hline & Residual & 1,568 & 30 & 052 & & \\
\hline & Total & 30,242 & 32 & & & \\
\hline
\end{tabular}


Dari tabel di atas diperoleh nilai $F_{\text {hitung }}$ sebesar 274,396 dan nilai $F_{\text {tabel }}$ sebesar 3,32. dengan tingkat signifikansi 5\%. Ini menunjukkan bahwa hipotesis yang menetapkan "Skeptisme profesional dan kompetensi auditor berpengaruh signifikan terhadap jumlah temuan audit", diterima.

\section{PEMBAHASAN}

Dalam penelitian ini penulis mengambil beberapa refensi sebagai rujukan penelitian. Berikut beberapa hasil penelitian tersebut :

Hasil penelitian RR Kushasyandita yang berjudul : Pengalaman, Keahlian, Situasi Audit, Etika, dan Gender Terhadap Ketepatan Pemberian Opini Auditor melalui Skeptisisme Profesional Auditor, menunjukkan bahwa Keahlian dan skeptisme profesional auditor mempunyai hubungan yang erat terhadap opini akuntan. Hasil Penelitian S Noviyanti : Skeptisme Profesional Auditor Dalam Mendeteksi Kecurangan, menunjukkan hasil yang sama.

Hasil penelitian Adrian yang berjudul : Pengaruh Skeptisme Profesional, Etika, Pengalaman, Dan Keahlian Audit Terhadap Ketepatan Pemberian Opini Oleh Auditor, menunjukan hubungan yang erat dan positif antara skeptisme profesional dan keahlian terhadap opini akuntan. Demikian pula dengan penelitian penulis yang menunjukkan adanya hubungan yang erat dan positif serta terdapat pengaruh yang signifikan baik secara parsial maupun simultan antara Skeptisme Profesional dan Kompetensi auditor terhadap jumlah temuan auditor.

Dari beberapa kajian di atas, dapat diketahui bahwa Skeptisme profesional merupakan sikap seorang yang penuh kehati hatian dan ketelitian dengan membuat berbagai dugaan dan pertanyaan dalam pemeriksaan, sedangkan kompetensi merupakan kemahiran atau keahlian seorang auditor dalam mengaplikasikan ilmu dalam bidangnya, dengan didukung oleh kemampuan dalam berkomunikasi dan berstrategi dalam memperoleh bukti. Pengalaman dan jam terbang yang sangat memadai, serta up date informasi yang dimilikipun menjadi pendukung bagi seorang auditor dalam memperoleh jumlah temuan audit, karena pada dasarnya opini akuntan terlahir dari hasil pemeriksaan yang didukung oleh bukti dan temuan audit selama dilapangan.

\section{SIMPULAN}

Terdapat hubungan yang erat dan positif antara skeptisme profesional dan kompetensi auditor terhadap jumlah temuan auditor, serta terdapat pengaruh yang signifikan baik secara parsial maupun simultan antara skeptisme profesional dan kompetensi auditor terhadap jumlah temuan auditor.

\section{DAFTAR PUSTAKA}

Adrian , 2013, Pengaruh Skeptisme Profesional, Etika, Pengalaman, Dan Keahlian Audit Terhadap Ketepatan Pemberian Opini Oleh Auditor, Jurnal Akuntansi -

Agusti Restu dan Pertiwi Nastia Putri, 2013, Pengaruh Kompetensi, Independensi

Dan Profesionalisme Terhadap

Kualitas Audit ,Jurnal

Ekonomi, Volume 21

ejournal.unp.ac.id

Herawaty Arleen, Susanto Yulius Kurnia, 2010, Profesionalisme, Pengetahuan Akuntan Publik Dalam Mendeteksi Kekeliruan, Etika Profesi Dan Pertimbangan Tingkat Materialitas, Jurnal Profesionalisme dan Tingkat Materialitas

Hilmi, Fakhri. 2011. Pengaruh Pengalaman, Pelatihan dan Skeptisisme Profesional Auditor Terhadap Pendeteksian Kecurangan

IAI. 2016. Kode Etik Akuntan Profesional. Jakarta : Komite Etika IAI.

IAPI. 2010. Kode Etik Profesi Akuntan Publik. Jakarta : DSPAP-IAPI.

IAPI. 2011. Standar Profesional Akuntan Publik. Jakarta : Salemba Empat.

IAPI. 2013. Kerangka untuk Perikatan Asurans. Jakarta : DSPAP-IAPI. 
Kushasyandita RR 2012, Pengalaman,

Keahlian, Situasi Audit, Etika, dan

Gender Terhadap Ketepatan

Pemberian Opini Auditor melalui

Skeptisisme Profesional Auditor, eprints.undip.ac.id

Kusumastuti Ratri Nur, 2012, Analisis Faktor -

Faktor Yang Berpengaruh Terhadap

Kecenderungan Kecurangan

Akuntansi Dengan Perilaku Tidak

Etis Sebagai Variabel Intervening,

Diponegoro journal of accounting

Volume 1, Nomor 1, Halaman 1-15

http://ejournal-

s1.undip.ac.id/index.php/accounting

Moeller Robert, Brink, 2009, Modern Internal

Auditing: A Common Body Of

Knowledge, 7th edition, John Wiley

$\&$ Sons, Inc

Noviyanti S, 2008, Skeptisme Profesional Auditor

Dalam Mendeteksi Kecurangan, Jurnal

Akuntansi dan Keuangan Indonesia ,jaki.ui.ac.id

SK Menteri Keuangan No.43/KMK.017/1997

tanggal 27 Januari 1997.

Sugiyono, 2013, Metode Penelitian, Bandung,

Alfabeta

Tuanakotta, Theodorus M. 2015. Audit

Kontemporer. Jakarta : Salemba

Empat.

www.masimam.com, 2016, Kompetensi

Auditor internal, html 